UDC 070133

\title{
Fight against Disinformation in Ukraine: Challenges and Prospects
}

\author{
Alexander A. Vasiliev ${ }^{1}$, Shuanat N. Kadyrova ${ }^{2} \rrbracket$, Alexander A. Fomin ${ }^{2}$ \\ ${ }^{1}$ Information and Analytical Center "Perspective", \\ 40A Obolonskii Prospekt, Kyiv, 04214, Ukraine \\ ${ }^{2}$ Peoples' Friendship University of Russia (RUDN University), \\ 10 Miklukho-Maklaya St, bldg 2, Moscow, 117198, Russian Federation \\ $\square$ kadyrova_shn@rudn.ru
}

\begin{abstract}
The material presents the analysis of the draft law of Ukraine On Amendments to Certain Legislative Acts of Ukraine Regarding Ensuring National Information Security and the Right of Access to Reliable Information. This law can for the first time in the history of the country criminalize journalists for disseminating false information and set up new forms of control over information in the future. This is not the first attempt by the country's leadership to bring all actors into a legal and civilized channel (the draft law On the Media No. 2693, which is also under consideration by the Verkhovna Rada of Ukraine, stands for the systematic policy of reforming the media sector of Ukraine). The research is aimed at defining the place of the draft law in the reformed system of legal regulation of the Ukrainian media, from the position of the academic community neutral to the process. For this purpose, a detailed content analysis was conducted, which showed that, in the long run, the ambiguous wording of the adopted document at the stage of its enforcement, leaves the regulatory authorities free to interpret it depending on the interests of the parties, rather than on the language of the law. Considering the risks associated with the entry into force of this draft, one should also take into account the ambiguous reaction of the local and international media community. The article may be considered as a contribution to the development of criteria for a comprehensive scientific analysis of the legislation regulating the activity of media structures.
\end{abstract} tics, law

Keywords: journalism, media, information, disinformation, freedom of speech, poli-

Conflicts of interest. The authors declare that there is no conflict of interest.

Article history: submitted December 6, 2020; revised December 28, 2020; accepted February 15, 2021.

For citation: Vasiliev, A.A., Kadyrova, Sh.N., \& Fomin, A.A. (2021). Fight against disinformation in Ukraine: Challenges and prospects. RUDN Journal of Studies in Literature and Journalism, 26(2), 294-301. http://dx.doi.org/10.22363/2312-9220-2021-26-2-294-301

(C) Васильев А.А., Кадырова Ш.Н., Фомин А.А., 2021

(C) This work is licensed under a Creative Commons Attribution 4.0 International License https://creativecommons.org/licenses/by/4.0/ 


\title{
Борьба с дезинформацией на Украине: проблемы и перспективы
}

\author{
А.А. Васильев ${ }^{1}$, Ш.Н. Кадырова ${ }^{\circledR} \rrbracket$, А.А. Фомин ${ }^{2}$ \\ ${ }^{1}$ Информационно-аналитический цеентр «Перспектива», \\ Украина, 04214, Киев, Оболонский пр-кт, д. $40 \mathrm{~A}$ \\ ${ }^{2}$ Российский университет дружбы народов, \\ Российская Федерация, 117198, Москва, ул. Миклухо-Маклая, д. 10, корп. 2 \\ $\varangle$ kadyrova_shn@rudn.ru
}

\begin{abstract}
Аннотация. Представлен анализ проекта закона Украины «О внесении изменений в некоторые законодательные акты Украины касательно обеспечения национальной информационной безопасности и права на доступ к достоверной информации», который может впервые в истории страны ввести уголовную ответственность журналистов за распространение недостоверной информации и выстроить новую архитектуру контроля над информацией в будущем. Это не первая попытка руководства страны вывести всех акторов в легальное и цивилизованное русло (в пользу системной политики реформ медийной отрасли Украины говорит находящийся также на рассмотрении ВРУ проект закона «О медиа» № 2693). Основной задачей исследования является попытка определить место законопроекта в реформируемой системе правового регулирования деятельности СМИ Украины с позиции нейтрального к процессу научного сообщества. Для этого был проведен детальный контент-анализ, который показал, что в перспективе двусмысленные формулировки принимаемого документа на этапе его правоприменения оставляют контролирующим органам свободу трактовать их в зависимости от интересов сторон, а не исходя из буквы закона. В учете рисков, связанных с вступлением в силу данного проекта, следует принимать во внимание и неоднозначную реакцию на него медийного сообщества как внутри страны, так и на международном уровне: к обсуждению инициативы подключились профильные комиссии Евросоюза и ООН. Таким образом, предлагаемый материал может представлять интерес и рассматриваться как вклад в дело выработки критериев комплексного научного анализа законодательства, регламентирующего деятельность медийных структур.
\end{abstract}

Ключевые слова: журналистика, медиа, информация, дезинформация, свобода слова, политика, право

Заявление о конфликте интересов. Авторы заявляют об отсутствии конфликта интересов.

История статьи: поступила в редакцию 6 декабря 2020 г.; принята к публикации 15 февраля 2021 г.

Для цитирования: Vasiliev A.A., Kadyrova Sh.N., Fomin A.A. Fight against disinformation in Ukraine: Challenges and prospects // Вестник Российского университета дружбы народов. Серия: Литературоведение. Журналистика. 2021. Т. 26. № 2. С. 294-301. http://dx.doi.org/10.22363/2312-9220-2021-26-2-294-301

According to the regular ratings of the Reporters Without Borders organization, the situation around freedom of speech in Ukraine since its independence has evolved ambiguously ${ }^{1}$. This is largely due to the long and difficult stages of

${ }^{1}$ Thus, the highest indicators of freedom of speech were recorded from 2007-2009 (92nd, 87th, 89th positions), the worst figures were noted in 2003, 2004, as well as in the period from 
the transition from the Soviet totalitarian system of relations between the state and the media to attempts to build a libertarian model (see [1]).

As of 2020, the TV market in Ukraine was divided between media structures belonging to four main financial and industrial groups: TV holding StarLightMedia (owner - Victor Pinchuk); holding "1 + 1 Media" (Igor Kolomoisky); media group "Ukraine" (Rinat Akhmetov); media holding "Novosti" (Taras Kozak and Viktor Medvedchuk) $)^{2}$. It is becoming increasingly difficult to control such a diversified structure. Special legislation that can bring all actors into a civilized and legal channel is required.

The draft law On Disinformation ${ }^{3}$, submitted for public consideration before being presented to the Verkhovna Rada of Ukraine on the initiative of the Ministry of Culture in January 2020 [2], caused a mixed reaction from the media community, both locally and internationally. The Council on Freedom of Expression and Protection the Rights of Journalists under the President of Ukraine called for the draft law to be revised as it "does not meet the stated goals and objectives", which is the fight against disinformation. Instead, it restricts freedom of speech and the rights of journalists in the country as well as promotes self-censorship. Among other things, the introduction of criminal liability for journalists, unjustified administrative and legal sanctions, state interference in the issues of selfregulation of journalists, the subjective division of authors into "professional" and simply "journalists" have been subjected to criticism. The proposal to establish the institution of the Commissioner for Information (a structure that may appear in the case of the adoption of this law) is doubtful in the opinion of experts [3].

International organizations also have joined in the discussion of the legislative initiative, in particular the United Nations (UN) monitoring mission in Ukraine, which considers the bill on countering disinformation to be inconsistent with international human rights standards and calls on the authorities to refrain from setting restrictions on the work of the media. "We call on the Ukrainian authorities to refrain from imposing unnecessary restrictions on the work of the media. We share the concern of the media and civil society that the current draft law on disinformation does not meet international human rights standards, may undermine freedom of the media, and lead to self-censorship," the monitoring mission said in a statement [4].

The mission notes that an attempt to criminalize the dissemination of disinformation can result in harassment of journalists simply for doing their job. Besides, the state should refrain from creating bodies responsible for monitoring and

2013-2015 (132nd, 138th, 126th, 127th, and 129th). As of 2019-2020, Ukraine was ranked 102 and 96, respectively (See: Reporters Without Borders. (n.d.). Rating of Ukraine in freedom of speech index. Retrieved February 1, 2021, from https://rsf.org/en/ukraine; Ukraine is on TOP 100 on the matters of freedom of speech. (2020, April 21). Kontrakty. Retrieved February 1, 2021, from https://kontrakty.ua/article/154713, etc.).

2 At the time of this writing, the "Novosti" media holding and its owners fell under the sanctions of the National Security and Defense Council of Ukraine No. 43/2021 dated February 2, 2021. Thus, de jure, the activities of the media structure are blocked

${ }^{3}$ The Disinformation draft law is an unofficial name for the proposed changes, but common in all international reports and media. Official title: Amendments to the Draft Law of Ukraine: On Amendments to Certain Legislative Acts of Ukraine Concerning Ensuring National Information Security and the Right to Access Reliable Information. 
filtering content. Fighting disinformation and fakes, according to the mission, is necessary, but not at the expense of restricting media freedom.

The Council of Europe, referring to the analysis of the NSJU, also opposed some provisions of the draft law On Disinformation. Thus, the Council's message noted that its adoption would legitimize state interference in journalistic activities and limit the rights of media workers [5]. NSJU initially strongly rejected the bill in its current form. "If this law is passed, journalists will be required to have a professional press card from a state-sponsored organization; the content of the media will be controlled by a special commissioner who will implement the policy of fines, blocking, and sanctions; a confidence index will be introduced based on criteria developed by the commissioner; the status of a professional journalist will be granted and revoked under the Code of Journalism Ethics; and the media will be required to publish official identification information, "the NSJU said [6].

In response to criticism, the authors of the project point out that the law aims to protect the information security of the state and the rights of citizens to access reliable information. The department assures that the main task is not to intimidate journalists but to raise the level of their professional responsibility. Attention is also drawn to the fact that "censorship in the media is prohibited," and the project provides for many mechanisms to protect a professional journalist honestly performing his/her professional duties [7].

However, the document contains clauses according to which restrictions on freedom are possible "if it is necessary for a democratic society, and the corresponding restriction is proportional to the aim pursued."

The analysis of the text of the draft law On Disinformation made it possible to identify several ambiguous and potentially conflicting provisions of the document. Let's say the key term is "disinformation". According to the draft law, this is "false information on issues of public interest. In particular: national security, territorial integrity, sovereignty, defense capability of Ukraine, the right of the Ukrainian people to self-determination, life and health of citizens, the state of the environment" [2].

Such a broad interpretation of the term creates the threat of revealing "disinformation" in any material published in the media. For example, in the context of public discussion about the date of Ukrainian state self-determination: is it 1991 (collapse of the USSR), 1917-1919 (Civil war and the founding of the UPR and WUPR), or the times preceding the emergence of Kievan Rus? ${ }^{4}$

It is difficult to say why the authors did not use generally accepted terminological definitions in their work on the project. The Oxford Living Dictionary, for example, cites the following: "Disinformation is false information that is intended to mislead, especially propaganda disseminated by a government organization against competing authorities or the media." As it is seen, the initiators have chosen a defensive-offensive tactic for the model of the project, in which the state is not a priori a source of disinformation to opponents. So, paragraph 2 art. $21 \mathrm{sec}-$ tion III Information Security, the Right to Reply and Refutation of Disinformation presents the following consequences of disinformation: "The dissemination of dis-

${ }^{4}$ In the Textbook with Geography for 8th Grade [8] the author's position is presented, according to which self-determination of Ukrainians happened even before the appearance of Kievan Rus (IX century) (p. 274). 
information and other inaccurate information can lead to a distorted perception of reality and decision-making that is based on untrue, incomplete or twisted information. This situation negatively affects the democratic processes in Ukraine and creates a threat to national information security" [2]. Even if we do not consider the style of presentation, which is dubious for a document adopted at the state level, such an inaccuracy of wording and a categorical position can become a springboard for the infringement of the rights of citizens.

According to the draft law, disinformation is subject to criminal or administrative liability, this is a serious factor of pressure on freedom of expression and the introduction of self-censorship.

So, the spread of disinformation, according to Art. 55 Section IV, in case of voluntary refutation, starting with the third violation within one year, will be punished with a fine of 1,000 minimum wages ${ }^{5}$ (UAH 4.7 million) for each violation. Refusal to voluntarily refute will entail a fine of 2000 minimum wages (UAH 9.4 million) for each case. Besides, the removal of such material or change of its address will result in a fine of 5 minimum wages (UAH 23.6 thousand). But constant mass disinformation about facts that present a threat to national security and territorial integrity will be punished with a fine from 5,000 to 10,000 non-taxable minimums or correctional labor for up to 2 years. The maximum punishment in the form of imprisonment up to 7 years is provided for repeated mass disinformation by an organized group, which led to serious consequences or caused large-scale material damage. "Responsibility for disinformation is provided only for the period of Russian aggression until the restoration of the territorial integrity of Ukraine," the authors emphasize. In our opinion, the vagueness of the wording "grave consequences" and "Russian aggression" pose the greatest threat to freedom of speech. The fact is that there has already been a similar precedent in the Ukrainian criminal law.

Journalist Pavel Volkov was arrested by the SSU on September 27, 2017. Volkov was accused of assisting a terrorist organization (part 1 of Article 258-3 of the Criminal Code) and separatism (part 3 of Article 110 of the Criminal Code). The accusation of complicity in terrorism was based on the fact that Volkov, on the instructions of the Committee for Social Communications under the People's Council of the DPR, filmed videos and wrote articles about separatists in Donbas and the situation in the region. From the press service of the department, it followed that he called for a change in the territorial integrity and inviolability of the Ukrainian borders and "provoked incitement of ethnic hatred" [9].

Over time, the lawyers managed to re-qualify the articles of the accusation for part 2 of Art. 110 of the Criminal Code of Ukraine - "encroachment on the territorial integrity of Ukraine", as well as part 3 of Art. 258 - "assistance to a terrorist organization."

On March 27, 2019, the first instance court acquitted journalist Volkov. The verdict was upheld by all the higher courts. On April 3, 2020, the Supreme Court of Ukraine rejected the prosecutor's appeal and fully upheld the acquittal. On December 2, 2020, the Zaporizhzhya Court of Appeal decided to recover UAH 600 thousand from the state as compensation to a journalist for illegal persecution ${ }^{6}$.

\footnotetext{
${ }^{5}$ The minimum wage in Ukraine in 2020 is UAH 4723.

${ }^{6}$ Information from the resource Judicial Power of Ukraine on a request for a single unique case number 336/5772/20.
} 
Besides, separate norms introduce full control over the professional status of a journalist by introducing special press cards issued by the Association of Professional Journalists of Ukraine (a state organization that is created according to the draft law. $-A . V$., Sh.K., A.F.). It is planned to issue press cards of two types: "professional" and "ordinary". Holders of the first type will be endowed with broad rights (more details below). In the second case, the authors will be limited in access to information and protection of their interests. It is noteworthy that today in Ukraine all journalists, regardless of their form of ownership and editorial policy of officially operating media, have equal rights [10].

But the main threat to the freedom of activity of a journalist is that his/her status as a "professional journalist" will be canceled in case of violation of the Code of Professional Ethics approved based on the draft law [2].

Thus, professional journalists will be those who have received accreditation in the Association of Professional Journalists of Ukraine (hereinafter referred to as the Association) or have accreditation of a foreign journalist, according to the Register of Accredited Foreign Journalists (Section IV Self-Government of Journalists, Articles 29, 36, 38).

For accreditation in the Association, the author will have to accept and adhere to the Code of Professional Ethics of Journalists and have confirmation of the experience of the main work as a journalist based on a labor or other contract with a Ukrainian or foreign subject in the media for at least three years. Accreditation can be obtained by submitting an online application.

Any other press cards or badges will not entitle journalists to enjoy the privileges associated with their professional activities.

According to the current law On Print Media (Press) in Ukraine (2782-XII as amended on 03.07.2020), now the status of a journalist is confirmed by an editorial certificate or other document issued to him/her by the editorial board of the media [10]. The same law states that the professional affiliation of a journalist can be confirmed by a document issued by a professional association of journalists (for example, the National Union of Journalists of Ukraine). It shows the duplication of existing laws and the creation of parallel NSJU organizations that will formally consolidate the segregation of the journalistic community.

The situation is further aggravated by the fact that along with the increase in requirements for those who can be considered "professional journalists", the range of their privileges is also expanding (Article 39 of Section IV):

- to collect information in emergency zones, including areas of natural disasters, catastrophes, in places of accidents, riots, places of anti-terrorist operations (ATO), and operations of the Joint Forces (OJF);

- have an annual leave of 36 calendar days at the expense of media entities (instead of 24 days);

- retire early (from 55 years old for men and from 50 years old for women, in case of 25 or 20 years of experience, respectively) and have one-time cash assistance in the amount of 50 minimum wages (UAH 113.5 thousand in 2020) in case of wounds, contusions, mutilations received in the line of duty in places of emergency. Also, an operator and a photojournalist who worked with such a journalist may retire early;

- if a journalist is searched, the journalist must be warned about it no later than 24 hours before the search, the presence of a lawyer from the Association is also 
guaranteed, and the opportunity to invite no more than three members of the Association as witnesses. The project also defines other special guarantees for journalists.

That is, we see in the proposed bill as a punitive function of Art. 55 of Section IV in the form of fines and threats of criminal prosecution, and the stimulating Art. 39 section IV in the form of additional leave, expanded rights to collect information and defend one's own interests.

The main innovation will be the emergence of a new institution - the Commissioner for Information (Article 49 of Section VI Commissioner for Information). The key role in determining the truthfulness or inaccuracy of information will be in its competence. It will examine with the help of representatives of the "fact-checking organizations" from the aforementioned Association. Presumably, we are talking about structures that position themselves as non-governmental organizations (NGOs) of the Ukrainian media market [2].

Because there are only a few generally recognized fact-checking organizations in the Ukrainian media field, it seems that we are talking about the Institute of Mass Information and Media Detector. A certain problem here is that the activities of these structures have long raised questions from a significant part of Ukrainian journalists, who noted that their experts do not notice, and sometimes directly justify the pressure of the authorities on the media, and violations of journalistic standards are found mainly in the opposition media [11]. The same "symbiosis of the state/civil society" will check the news, according to a sample not specified in the draft law, for reliability (there is a fear that content will fall under control based on the subjective opinion of the inspectors) and assign them a special state index (Section I General Provisions) [10]. Something similar is practiced in the UK, where the Global Disinformation Index (GDI) exists, a non-profit project whose reports have no legal or political implications, and whose opinions are advisory. In Ukraine, this index will be state-owned, which gives the theoretical right to officials to refuse accreditation or provide information to those media and journalists who have a low state index. And the assignment of the index can become an instrument of pressure on the editorial offices of the media and restrict their activities.

Thus, a situation is emerging in which the Ukrainian authorities, in an attempt to protect the national information space in the legal plane, can introduce state censorship and professional segregation of journalists. As a result, instead of fighting fake news in Ukraine, working tools are being created at the legislative level that allow dividing the professional media community into loyal and disloyal actors and choosing an appropriate policy towards them. The Information Commissioner performs the functions of an official censor, and attempts to introduce civil society representatives in the form of fact-checking organizations are more reminiscent of a cartel conspiracy in the media market.

\section{References}

[1] Siebert, F., Schramm, W., \& Peterson, T. (1998). Four theories of the press. Moscow, National Press Institute.

[2] Ministry of Culture Youth and Sports of Ukraine. (2020). Draft Law to change some norms in the current legacy about disinformation. (In Ukrainian.) Retrieved February 1, 2021, from http://mkms.gov.ua/files/pdf/Disinformation_Draft_2020.pdf 
[3] Zelenskiy's Freedom of Expression Council opposes disinformation law. (n.d.). Ukraine 24. (In Russ.) Retrieved February 1, 2021, from https://ua24ua.net/sovet-povoprosam-svobodi-slova-pri-zelenskom-vistupil-protiv-zakona-o-dezinformatsii/

[4] Vatsyak, J. (2020). Mission UN against of Ukrainian law about disinformation. Ukrainian News. (In Russ.) Retrieved February 1, 2021, from https://ukranews.com/news/681020zakon-o-media-borodyanskogo-prokommentirovali-v-oon

[5] Council of Europe. (n.d.) Ukraine's Draft Law on Combating Disinformation and Regulating Media Activity threatens freedom of speech. Retrieved February 1, 2021, from https://www.coe.int/en/web/

[6] Disinformation bill threatens freedom of speech in Ukraine - Council of Europe. (2020, January 28). Strana.ua. (In Russ.) Retrieved February 1, 2021 from https://strana.ua/news/246772-sovet-evropy-osudil-zakonoproekt-o-dezinformatsii.html

[7] There is much of lies about the project of the law about disinformation. (2020, January 25). Ukrinform. (In Russ.) Retrieved February 1, 2021, from https://www.ukrinform.ru/rubricsociety/2862785-pro-zakonoproekt-o-dezinformacii-pisut-mnogo-nepravdy-borodanskij.html

[8] Maslyak, P.O., \& Kapirulina, S.L. (2016). Textbook with Geography for 8th grade. Kamyanets Podolsky, Axioma Publ. (In Ukrainian.)

[9] Volkova, O. (2018). Pavel Volkov: "By the number of corpses that hung on me, I was the most dangerous in prison". Strana.ua. (In Russ.) Retrieved February 7, 2021, from https://strana.ua/articles/168259-po-kolichestvu-trupov-kotorye-na-mne-viseli-2-tysjachchelovek-ja-byl-samym-opasnym-v-tjurme-.html

[10] The Law of Ukraine about Print Media and Press in Ukraine. (In Russ.) Retrieved February 1, 2021, from http://consultant.parus.ua/?doc=003PVDA8DC

[11] Tovt, A. (2018). Lawyers for lawlessness. Who and how helps the authorities to put pressure on the Ukrainian media. Strana.ua. (In Russ.) Retrieved February 1, 2021, from https://strana.ua/articles/analysis/131050-detektor-media-i-imi-iskazhajut-situatsijuso-svobodoj-slova-v-ukraine.html

\section{Bio notes:}

Alexander A. Vasiliev, $\mathrm{PhD}$ in History, expert, Information and Analytical Center "Perspektiva".

Shuanat N. Kadyrova, PhD in Philology, senior lecturer, Department of Theory and History of Journalism, Faculty of Philology, Peoples' Friendship University of Russia (RUDN University).

Alexander A. Fomin, PhD student, Department of Theory and History of Journalism, Faculty of Philology, Peoples' Friendship University of Russia (RUDN University.

\section{Сведения об авторах:}

Васильев Александр Александрович, кандидат исторических наук, эксперт, информационно-аналитический центр «Перспектива».

Кадырова Шуанат Набиевна, кандидат филологических наук, старший преподаватель, кафедра теории и истории журналистики, филологический факультет, Российский университет дружбы народов.

Фомин Александр Александрович, аспирант, кафедра теории и истории журналистики, филологический факультет, Российский университет дружбы народов. 